IIUC STUDIES

ISSN 1813-7733

Vol.- 6, June 2010 (p 7-34)

\title{
Classroom Situation in Reading Classes of the Foundation English Course (FEC) at International Islamic University Chittagong (IIUC): An Empirical Study
}

\author{
Mohammad Riaz Mahmud*
}

\begin{abstract}
The article aims at depicting the present scenario of teaching reading skill to the students of Foundation English Course (FEC) through an empirical study. Two questionnaires have been used for collecting data from learners and teachers to point out the weak areas of ineffective teaching and to identify the shortcomings in teaching reading skill. Collected data have been analyzed under eight points and recommendations have been made separately under those points to overcome the weak areas of ineffective teaching.
\end{abstract}

\section{Introduction:}

The Foundation English Course (FEC) aims at improving the efficiency in English for those undergraduate students in various departments who fail to pass the English Proficiency Test (EPT) after their admission at International Islamic University Chittagong (IIUC). This FEC program helps them pursue their degree effectively so that they can contribute significantly to their respective fields in practical life as professionals, where skills of English will give them an extra edge. The FEC program consists of three courses Reading Skill (FEC1101), Writing Skill (FEC-1102) and Listening \& Speaking Skills (FEC-1103/1104); and seventy (70) contact hours are offered for each course. An attempt was made in Autumn Semester 2005 to depict the scenario of teaching reading skill in FEC classes so that the authority can address the identified shortcomings.

* Assistant Professor, Department of English Language \& Literature, IIUC 
Teaching and learning scenario in various contexts in Bangladesh has been discussed in various research articles. Khan and Ismail (2000), for example, discuss the success of English Language Teaching Improvement Project (ELTIP) in bringing about change in the practices and attitudes of the secondary school teachers of Bangladesh. The authors interviewed, in two phases: before and at the end of the training, eight trainee teachers both by administering questionnaires and recording their opinions on the cassettes. This article does not cover classroom activities of the teachers, evaluation system, teaching materials, and learners' participation in classroom activities. Chowdhury (2001) explores several neglected and overlooked aspects of Communicative Language Teaching (CLT), highlights the inevitable interrelatedness of language and culture, point outs cultural problems associated with the implementation of CLT at the University of Dhaka and suggests ways to overcome it. Here we find a theoretical analysis of the Foundation Course, taught to the students of the Faculty of Arts, to adapt rather than adopt Westernized forms of CLT to meet the immediate needs. Though it recognizes the local constraints operating within the non-native cultural framework, we do not find discussion on real classroom situation, and problems and attitudes of the teachers and learners. Chowdhury (2002) discusses the problems faced by female students of Rajshahi University as far as English is concerned. 50 female students of Rajshahi University were interviewed for this purpose. Random sampling method was used in the study. The interviews were conducted through a questionnaire and through open discussion. Data were also collected from personal observation. This article does not highlight learners' problems in the real classroom. Mahmud (2003) discusses the ways of learning English in a non-native background and the limitations of effective teaching in a non-native country like Bangladesh. Mahmud (2004) uses two separate questionnaires for learners and teachers to examine the existing scenario of teacher-student interactions both inside and outside the UREL (University Required English Language) classrooms at International Islamic University Chittagong (IIUC). The article aims at facilitating better English teaching and learning within the constraints by identifying the real problems and suggesting recommendations for teachers, learners and the authority of the university. None of these articles have covered the area undertaken for this study. That is why the area of this article seems worth exploring. 


\section{Objective of the Study:}

The author aims at depicting the present scenario of teaching reading skill to make it more effective by pointing out the weak areas of ineffective teaching and suggesting ways of overcoming them to ensure a uniform quality of teaching to uphold the image of the university in the competitive market.

\section{Methodology of the Study:}

For depicting the real classroom situation, two questionnaires were set keeping an eye on the techniques of teaching reading skill in a nonnative context. Simple random sampling method was used for collecting data through questionnaires. One questionnaire [as in Appendix-2] was filled up by five (5) faculty members teaching reading skill and another [as in the Appendix-1] was filled up by seventy-three (73) FEC learners of the Departments of BBA, CSE, $\mathrm{CCE}$, and Law of International Islamic University Chittagong (IIUC). The collected data were analyzed to depict the existing ways of teaching reading skill and to identify the shortcomings regarding (1) Pre-reading activities, (2) Reading inside the classroom, (3) Reading lessons, (4) Vocabulary, (5) Evaluation system, (6) Learner, (7) Teacher, and (8) Teaching technique. The present situation and recommendation for the eight points mentioned above have been presented as per the findings from the Learners' Questionnaire and Teachers' Questionnaire Survey. The findings are based on about $50 \%$ of the opinions of learners and teachers.

\section{Findings of the Study:}

\section{(1) Pre- reading activities}

\section{Present situation of 'pre- reading activities' as per Learners' Questionnaire Survey}

The percentage of learners giving opinion, regarding pre-reading activities offered by their teacher, in the following cases:

i) Giving idea about the topic $-73.97 \%$

ii) Arousing interest about the text $-50.68 \%$

v) Asking general questions on the given text $-49.31 \%$ 
Present situation of 'pre- reading activities' as per Teachers' Questionnaire Survey

The percentage of teachers giving opinion, regarding pre-reading activities, in the following cases:

i) Giving students idea about the topic $-100 \%$

ii) Arousing interest among the students about the text - $80 \%$

iv) Asking students questions on the similar objects or ideas discussed in the text $-60 \%$

vi) Asking students specific questions on themes / points or about the characters of the known text $-60 \%$

\section{Recommendation for 'pre- reading activities':}

1. The teachers should do the following for pre-reading activities:

a) giving students ideas about the topic

b) asking general questions on the given text

c) arousing interest among the students about the text as Parry and Bartram say, "This interest might be aroused by an introductory discussion, by finding out the students' personal experience of the topic, or by giving the students a quiz about the subject. $(1989,6)$. Lindsay and Knight also say, "Pre-reading activities are designed to: set a task for the learners, help the learners prepare for the task and motivate the learners to read." $(2006,75)$ and "Prereading activities should help the learners achieve the aims of the activity, i.e. stimulate what they already know about the topic, provide them with background information that they need before they read and help them with words and phrases they will need to know." $(2006,76)$

\section{(2) Reading inside the classroom}

Present situation of 'reading inside the classroom' as per Learners' Questionnaire Survey

The percentage of learners giving opinion, regarding loud reading in classroom, in the following case: practicing correct pronunciation, stress and intonation $-65.75 \%$ 
The percentage of learners giving opinion, regarding benefits of loud reading in classroom, in the following cases:

helps to learn and practice correct pronunciation, stress and intonation $-65.75 \%$;

helps students to develop speaking $-69.86 \%$

The percentage of learners giving opinion, regarding doing silent reading in classroom, in the following case: before doing exercises under an unseen text $-67.12 \%$;

The percentage of learners giving opinion, regarding benefits of silent reading in classroom, in the following cases: helps to understand text better $-67.12 \%$;

Reader can think personally about the text $-52.05 \%$.

The percentage of learners giving opinion, regarding benefits in a cooperative class, in the following cases: facilitates understanding of the unseen text $-63.01 \%$;

allows weaker students to see how the better readers work at the text $63.01 \%$;

Classroom lessons become interesting and enjoyable $-67.12 \%$.

$32.87 \%$ learners say that the percentage of the students' participation in the total duration of the classroom activities is $20 \%-25 \%$.

$38.35 \%$ learners say that the percentage of teacher $>$ student interaction in the total duration of the classroom activities is $20 \%-25 \%$.

$43.83 \%$ learners say their teacher introduces them with the authentic texts in English for pleasure reading.

$54.79 \%$ learners say their teacher encourages them to do pleasure reading outside the classroom.

$45.20 \%$ learners say their teacher take time after the lesson to tell them the answer of the exercises and how these answers were arrived at.

$53.42 \%$ learners say their teacher sometimes translates every sentence in Bengali while discussing the text in classroom.

$50.68 \%$ learners say their teacher expresses every sentence easily in

English while discussing the text in classroom.

Present situation of 'reading inside the classroom' as per Teachers' Questionnaire Survey

The percentage of teachers giving opinion, regarding loud reading in classroom, in the following cases: checking the answers of the exercises $-60 \%$;

practicing correct pronunciation, stress and intonation $-80 \%$ 
The percentage of teachers giving opinion, regarding students' benefits while doing loud reading in classroom, in the following cases: helps to learn and practice correct pronunciation, stress and intonation $-80 \%$;

helps others to get benefit by listening $-60 \%$;

teacher can help a loud reader $-60 \%$;

The percentage of teachers giving opinion, regarding doing silent reading in classroom, in the following cases: before doing exercises under an unseen text $-60 \%$;

for any creative writing following the passage of the lesson $-60 \%$;

before classroom discussion $-60 \%$;

The percentage of teachers giving opinion, regarding students' benefits while doing silent reading in classroom, in the following case: reader can think personally about the text $-100 \%$.

The percentage of teachers giving opinion, regarding students' benefits in a cooperative class, in the following cases:

inspires learners to participate in group work and pair work $-60 \%$;

allows weaker students to see how the better readers work at the text $80 \%$;

classroom lessons become interesting and enjoyable $-80 \%$.

$80 \%$ teachers say that the percentage of the students' participation in the total duration of the classroom activities is $25 \%-30 \%$.

$60 \%$ teachers say that the percentage of teacher $>$ student interaction in the total duration of the classroom activities is $25 \%-30 \%$.

$60 \%$ teachers introduce the students with the authentic texts in English for pleasure reading.

$80 \%$ teachers encourage the students to do pleasure reading outside the classroom.

$80 \%$ teachers give time after the lesson to tell the students the answer of the exercises and how these answers were arrived at.

$80 \%$ teachers sometimes translate every sentence in Bengali while discussing the text in classroom.

$80 \%$ teachers express every sentence easily in English while discussing the text in classroom.

\section{Recommendation for 'reading inside the classroom':}

1. The teachers should make students do loud reading in the classroom for: 
a) practicing correct pronunciation, stress and intonation, and listening

b) checking the answers of the exercises

2. The teachers should make students do silent reading in the classroom:

a) before classroom discussion

b) before doing exercises under an unseen text as Parry and Bartram say, the students may be serious while they are reading if they are given some linguistic task ('Make a list of all the vocabulary you expect to find in the text, and then read it to see if you were right') or non-linguistic ('Draw a diagram based on the information in the text') or subjective/personal ('Does this text make you feel happy, sad or angry?'). (1989, 6)

c) for any creative writing following the passage of the lesson (for making them think personally about the text)

3. The teachers should ensure a cooperative class for:

a) inspiring learners to participate in group work and pair work as Driscoll says, " To reflect the real world, and to encourage the ongoing process of learning, allow and encourage students to work together in pairs while they are reading the same text." $(2004,8)$

b) allowing weaker students to see how the better readers work at the text as Parry and Bartram say, the activities in pairs or groups increase the co-operative atmosphere in the class and allow weaker readers to see how the better readers work at the text, using all the resources at their disposal to extract the meaning. $(1989,7)$

c) making classroom lessons interesting and enjoyable

d) facilitating understanding of the unseen text.

4. The percentage of the students' participation in the total duration of the classroom activities should be $25 \%$.

5. The percentage of teacher $>$ student interaction in the total duration of the classroom activities should be $25 \%$. 
6. The teachers should:

a) introduce the students with the authentic texts in English and encourage them to do for pleasure reading outside the classroom as Parry and Bartram say, students should be encouraged to read what they want to read because too many people have been put off reading in English by being forced to read texts which were too heavy, too long, or largely irrelevant to them. (1989, 7) And Lindsay and Knight say, extensive reading is an excellent way of developing reading skills and increasing vocabulary, and learners should read as widely and as independently in English as they can. $(2006,74)$ Davies and Pearse also say, "the knowledge of the language necessary for reliable and efficient serious reading can probably be acquired to a large extent simply through reading extensively."'(2000, 94)

b) give time after the lesson to tell the students the answer of the exercises and how these answers were arrived at. Because Parry and Bartram rightly point out that the students will be able to transfer the skill to the next passage they read if the class discusses which answers were correct, and how these answers were arrived at, instead of simply giving a list of correct answers without comment. $(1989,6)$

c) express every sentence easily in English while discussing the text in classroom

d) avoid translating every sentence in Bengali while discussing the text in classroom as Davies and Pearse say, "Reading comprehension in a foreign language is not translation, though translation may occasionally be useful..'(2000, 91)

\section{(3) Reading Lessons}

\section{Present situation of 'reading lessons' as per Learners' Questionnaire Survey}

$50.68 \%$ learners think the reading lessons are adequate to help them develop their reading skill.

$58.90 \%$ learners say that their reading lessons are grammar and vocabulary focused.

The percentage of learners giving opinion, regarding emphasis in reading lessons, in the following cases: practicing grammar $-56.16 \%$; 
solving exercises based on the given text $-50.68 \%$;

understanding the main idea of the text $-61.64 \%$.

The percentage of learners giving opinion, regarding not enjoying reading lessons for the classroom activity, in the following case: lessons are difficult and not interesting $-56.16 \%$.

The percentage of learners giving opinion, regarding why reading lessons are not interesting, in the following case: difficult structure, new words and phrases $-76.71 \%$.

Present situation of 'reading lessons' as per Teachers' Questionnaire Survey

$60 \%$ teachers feel the number reading lessons used by them is enough to develop reading competence among the learners.

$60 \%$ teachers say sometimes their reading lessons are grammar and vocabulary focused.

The percentage of teachers giving opinion, regarding main focus in reading lessons, in the following cases: practicing grammar \& vocabulary- $80 \%$;

understanding the main idea of the text $-100 \%$.

The percentage of teachers giving opinion, regarding learners' not enjoying reading lessons for the classroom activity, in the following cases:

lessons do not match with students' social culture - $80 \%$;

language of the lessons is not suitable to their levels- $80 \%$;

teaching without arousing interest among the learners - $60 \%$.

The percentage of teachers giving opinion, regarding sources for the reading lessons, in the following cases: newspaper articles \& magazines $-80 \%$; Headway Series $-60 \%$.

\section{Recommendation for 'reading lessons':}

1. The reading lessons:

a) should be adequate enough to develop reading competence among the learners

b) should not be grammar and vocabulary focused

c) should emphasize understanding the main idea of the text and solving exercises based on the given text 
d) should be suitable to the levels of learners regarding language and subject matter

e) should be taught arousing interest among the learners as Davies and Pearse say, "Lessons should be dynamic, involving the learners in varied activities and interactions. $(2000,15)$

2. For the sources of the reading lessons newspaper articles \& magazines, Headway Series or any other standard books of practicing reading skill can be used.

\section{(4) Vocabulary}

\section{Present situation of 'vocabulary' as per Learners' Questionnaire Survey}

$41.09 \%$ learners sometimes ignore or skip over difficult words while doing reading.

$41.09 \%$ learners sometimes translate every word while doing reading. $50.68 \%$ learners usually become worried after seeing difficult words while reading an unseen text.

$47.94 \%$ learners sometimes guess meaning of unknown words while reading unseen text.

$42.46 \%$ learners sometimes use English to English dictionary to find the meaning of unknown words.

$53.42 \%$ learners maintain Vocabulary Note Book to note down the meaning of unknown words.

$53.42 \%$ learners spend 30 minutes regularly for using English to English dictionary outside theclassroom.

\section{Present situation of 'vocabulary' as per Teachers' Questionnaire Survey}

All teachers say students should ignore or skip over difficult words while doing reading.

$60 \%$ teachers say students should not translate every word while doing reading.

All teachers say students should not become worried after seeing difficult words while reading an unseen text.

$60 \%$ teachers encourage their students to guess meaning of unknown words while reading unseen text. 
$60 \%$ teachers encourage their students to use English to English dictionary to find the meaning of unknown words.

$60 \%$ teachers encourage their students to maintain Vocabulary Note Book to note down the meaning of unknown words.

$60 \%$ teachers advice their students to spend 30 minutes regularly for using English to English dictionary outside the classroom.

Recommendation for 'vocabulary':

1. Learners should:

a) ignore or skip over difficult words while doing reading as Day and Bamford say, constant stopping to look up words in a dictionary makes fluent reading difficult. $(1998,8)$

b) not translate every word while doing reading

c) not become worried after seeing difficult words while reading an unseen text

d) guess meaning of unknown words while reading unseen text as Majid says, "To understand the meaning of each sentence, the learners must learn to focus on the context of a word." $(2000,130)$

e) use English to English dictionary to find the meaning of unknown words as Mahmud says, the use of an English to English dictionary can develop learners' understanding of English rapidly. $(2003,28)$

f) spend at least 30 minutes regularly for using English to English dictionary outside the classroom as Day and Bamford say, second language students must develop a large general vocabulary through the reading of large amounts of comprehensible and interesting texts. $(1998,19)$.

g) maintain Vocabulary Note Book to note down the meaning of unknown words as Mahmud says, learners must increase their stock of words to be able to communicate properly and understand any written text while reading it. $(2003,29)$

\section{(5) Evaluation System}

Present situation of 'evaluation system' as per Learners' Questionnaire Survey 
$54.79 \%$ learners think that the evaluation system is faulty and not encouraging for them.

$58.90 \%$ learners say that their reading teacher has taken four class tests out of approximately sixty (60) classes.

The percentage of learners giving opinion, regarding components of their class tests, in the following cases: (serial as per questionnaire in Appendix-1)

i) Vocabulary $-63.01 \%$

ii) Multiple -choice items $\begin{array}{ll}\text { iii) Matching items }-65.75 \% & 53.42 \% \\ & \text { iv) True/false items-75.34\% }\end{array}$ vi) Summarizing the text- $50.68 \%$

Present situation of 'evaluation system' as per Teachers' Questionnaire Survey

$60 \%$ teachers think that the existing evaluation system can sometimes give feedback for the students' development in their reading competence.

$60 \%$ teachers say that they have taken six class tests out of approximately sixty (60) classes.

The percentage of teachers giving opinion, regarding components of class tests, in the following cases: (serial as per questionnaire in Appendix-2)

$\begin{array}{ll}\text { i) Vocabulary- } 80 \% & \text { iv) True/false items- } 60 \%\end{array}$

iii) Matching items- $60 \% \quad$ vi) Summarizing the text- $60 \%$

\section{Recommendation for 'evaluation system':}

1. The evaluation system should:

a) be proper in giving timely feed back to the learners

b) include one class test after every 6-7 classes

c) check the progress of learners' understanding and reproducing the ideas as Davies and Pearse say, "learners should be motivated by an awareness of their own progress" $(2000,14)$

(6)Learner

\section{Present situation of 'learner' as per Learners' Questionnaire Survey}

$68.49 \%$ learners feel enthusiastic to attend the reading class.

$43.83 \%$ learners sometimes maintain a list of problems, found while doing pleasure reading, to be discussed in the classroom. 
The percentage of learners giving opinion, regarding their unsatisfactory development in reading competence, in the following cases: (serial as per questionnaire in Appendix-1)

iii) Due to their own negligence - $49.31 \%$

iv) Due to no clear idea about practicing reading-56.16\%

Present situation of 'learner' as per Teachers' Questionnaire Survey

$60 \%$ teachers say the learners are enthusiastic/serious about their participation in the classroom activities.

$80 \%$ teachers say the learners sometimes maintain a list of problems, found while doing pleasure reading, to be discussed in the classroom.

The percentage of teachers giving opinion, regarding learners' unsatisfactory development in reading competence, in the following cases: (serial as per questionnaire in Appendix-2)

iii) Due to negligence of students- $80 \%$

iv) Due to unplanned classes- $60 \%$

\section{Recommendation for 'learner':}

\section{Learners should:}

a) be enthusiastic /serious about their participation in the classroom activities

b) maintain a list of problems, found while doing pleasure reading, to be discussed in the classroom as Lindsay and Knight say, "Effective learning is the result of the partnership between learner and teacher with both taking the responsibilities appropriate to their roles." $(2006,13)$

2. Teachers should:

a) give their students clear idea about practicing reading

b) make the students introduced with skimming, scanning, previewing and prediction, inference and intensive reading as Majid says, “... learners can be taught to become more competent readers by raising their consciousness to the kinds of strategies that work better in relationship to the kind of text they are reading." $(2000,130)$ 


\section{(7) Teacher}

\section{Present situation of 'teacher' as per Learners' Questionnaire Survey}

61.64\% learners say their teacher takes enough preparation for the
class.
$58.90 \%$ learners say they find their teacher sincere and punctual in
classroom.
$53.42 \%$ learners find their teacher as friend and facilitator in
classroom.
$50.68 \%$ learners say their teacher makes planning for giving an
interesting class.
$67.12 \%$ learners say they get sympathetic treatment from their teacher
in case of making wrong meanings from the context.
$83.56 \%$ learners say their teacher corrects their mistakes instantly.

Present situation of 'teacher' as per Teachers' Questionnaire Survey

$60 \%$ teachers say sometimes they get enough time to take preparation for the class.

$60 \%$ teachers can sometimes ensure sincerity and punctuality in classroom.

$80 \%$ teachers say that they should play the roles of friend and facilitator in a classroom.

$80 \%$ teachers sometimes make planning for giving an interesting class. $60 \%$ teachers treat students with sympathy in case of their making wrong meanings from the context.

$80 \%$ teachers correct students' mistakes instantly.

All teachers say students have favourable feelings for teachers, classmates and the procedure of conducting reading class.

$80 \%$ teachers say students have favourable feelings for reading materials.

$40 \%$ teachers say students like reading class environment.

$40 \%$ teachers say students are enthusiastic towards reading course under FEC.

$60 \%$ teachers say students like subject matter of reading lessons.

The percentage of teachers giving opinion, regarding students' shortcoming, in the following cases : guessing the meaning of a word $60 \%$; vocabulary $-80 \%$; grammar $-80 \%$. 


\section{Recommendation for 'teacher':}

1. Teachers should:

a) ensure sincerity and punctuality in classroom

b) should play the roles of friend and facilitator in a classroom as Chowdhury says, "The role of the teacher in CLT as 'facilitator', or 'manager' or sometimes 'co-communicator' encourages students to be active participants rather than inactive receptors" (2001, 184)

c) make planning for giving an interesting class

d) treat students with sympathy in case of their making wrong meanings from the context as Lindsay and Knight say, "It is often easier for people who are confident in themselves to learn a language than it is for those who have low self-confidence." (2006, 10)

e) not correct students' mistakes, in case of speaking, instantly as Communicative Language Teaching (CLT) focuses on fluency as much as accuracy

f) put emphasis on guessing the meaning of a word.

2. Students should have favourable feelings:

a) for teachers, classmates and the procedure of conducting reading class

b) for reading materials, reading class environment, reading course under FEC, and subject matter of reading lessons as Day and Bamford say, "Favorable feelings for and experiences with the teacher, classmates, materials, activities, tasks, procedures, and so on can forge positive attitudes toward reading in the second language. Unfavorable feelings and ongoing experiences can lead to negative attitudes." $(1998,25)$ 


\section{(8) Teaching Technique}

\section{Present situation of 'teaching technique' as per Learners' Questionnaire Survey}

The percentage of learners giving opinion, regarding the ways of
identifying the problems by their teacher before imparting a lesson, in
the following cases:
i) Taking a test on vocabulary used in the text- $50.68 \%$
ii) Making them guess meaning of unknown words of the text- $63.01 \%$
iv) Asking them small questions on particular sentence structures used
in the text- $56.16 \%$
v) Making them answer questions on the text- $49.31 \%$
vi) Asking them to give a general idea of the text- $53.42 \%$
The percentage of learners giving opinion, regarding the ways of
teachers' feed back to learners about their improvement in reading
competence, in the following cases:
pointing out the mistakes without insulting - $47.94 \%$;
making friendly behaviour - $42.46 \%$.
$46.57 \%$ learners say the teaching method followed by their teacher is
effective.
$39.72 \%$ learners say their teacher always follows the same teaching
technique in all the classes.

Present situation of 'teaching technique' as per Teachers' Questionnaire Survey

The percentage of teachers giving opinion, regarding the ways of identifying learners' problem before imparting a lesson, in the following cases:

i) Taking a test on vocabulary used in the text $-60 \%$

ii) Making students guess meaning of unknown words of the text- $60 \%$

vi) Asking students to give a general idea of the text- $80 \%$

vii) Making students read and explain some lines- $80 \%$

viii) Making students read and explain some lines in group discussion$60 \%$

The percentage of teachers giving opinion, regarding motivating the students about their improvement in reading competence, in the following cases:

pointing out the mistakes without insulting $-60 \%$;

making friendly behaviour $-60 \%$;

taking class tests at regular intervals $-60 \%$ 
$60 \%$ teachers consider the classroom situation before selecting the teaching technique.

$80 \%$ teachers sometimes follow the same teaching technique in all the classes/ for all lessons.

$60 \%$ teachers share their experience in the classroom with their colleagues who teach reading skill.

$60 \%$ teachers perform the role of monitor while the reading is actually going on.

$40 \%$ teachers perform the role of supporter while the reading is actually going on.

\section{Recommendation for 'teaching technique':}

1. Before imparting a lesson, teachers should identify the problems of the learners in the following ways:

a) making students guess meaning of unknown words of the text

b) asking students to give a general idea of the text

c) making students read and explain some lines

2. Teachers should motivate the students by giving feedback about their improvement in reading competence in the following ways:

a) pointing out the mistakes without insulting as Davies and Pearse say, "To participate willingly, they must feel able and confident, not threatened by failure, reprimand, or ridicule." $(2000,15)$

b) making friendly behaviour

c) taking class tests at regular intervals

3. Teachers should:

a) consider the classroom situation before selecting the teaching technique

b) share their experience in the classroom with their colleagues who teach reading skill

c) perform the role of monitor and of supporter while the reading is actually going on as Driscoll says, "The teacher has two roles in the reading classroom. Particularly at the beginning of the lesson, the teacher is at the centre of the action - initiating discussion, 
handing out materials, giving instructions, checking feedback. But, while the reading is actually going on, the teacher's role is that of monitor, supporter and advisor. It is the students themselves who must do the reading." $(2004,8)$ And Davies and Pearse say that they "must take the lead in establishing a positive atmosphere, planning appropriate activities, encouraging learners and dealing with problems sensitively." $(2000,15)$

Conclusion: Reading is the core of all the four skills. It is the base upon which develop other three skills. It helps to improve the efficiency in listening, speaking, writing and of course the process of thinking as well. (Mahmud 2003, 26) The aim of the study was to evaluate the approach of teaching reading skill to the FEC students and help other teachers including the author to be efficient in the classroom. It also aimed at informing the authority about the real classroom situation so that they can address the identified shortcomings and develop a uniform system of teaching reading skill in FEC classes. If the recommendations under eight points - (1) Prereading activities, (2) Reading inside the classroom, (3) Reading lessons, (4) Vocabulary, (5) Evaluation system, (6) Learner, (7) Teacher, and (8) Teaching technique - are entertained, IIUC authority will be able to overcome the weak areas of ineffective teaching. To make the reading classes of FEC effective, the following things should be ensured: effective pre-reading activities for arousing interest among the learners, cooperative class, encouragement for pleasure reading, emphasis on guessing meaning of unknown words, timely feedback to learners improvement, students' clear idea about practicing reading, teachers' role as 'facilitator' in the classroom and as monitor and supporter during the actual reading.

\section{References:}

CHOWDHURY, F. D. (June 2002), English Language Problems among Female Students of Rajshahi University: An Empirical Study, J. Asiat. Soc. Bangladesh, Hum., 47(1), Dhaka, P.183-192.

CHOWDHURY, M. R. ( June 2001), "To west or not to west? The question of culture in adopting / adapting communicative language teaching at the University of Dhaka", J. Asiat. Soc. Bangladesh, Hum., 46(1), Dhaka, P. 183-194.

DAVIES, P. \& E. PEARSE (2000), Success in Teaching English, Oxford University Press. 
DAY, R. R. \& J. BAMFORD (1998), Extensive Reading in the Second Language Classroom, Cambridge University Press, Cambridge.

DRISCOLL, L. (2004), Reading Extra, Cambridge University Press, Cambridge.

KHAN, R. A. AND M. ISMAIL (November 2000), "To what extent has ELTIP been able to bring about a change in teachers' attitudes and practices?", English Language Teaching Improvement Project Bangladesh, Collected Papers of "Classroom Research Symposium", The British Council, Dhaka, P. 75-93.

LINDSAY, C. \& P. KNIGHT (2006), Learning and Teaching English (A Course for Teachers), Oxford University Press, Oxford.

MAHMUD, M. R. (December 2003), "Teaching and Learning English at the Tertiary Level in Bangladesh", IIUC Studies: Vol-1, Issue No.-1, P. 24-33

MAHMUD, M. R. (December 2004), "Teaching and learning English as required at International Islamic University Chittagong (IIUC): An Empirical Study", IIUC Studies: Vol.- 2, P.82-118

MAJID, I. A. N. (November 2000), "The reading habits of Bangladeshi learners at the tertiary level", English Language Teaching Improvement Project Bangladesh, Collected Papers of "Classroom Research Symposium", The British Council, Dhaka.

PARRY, A. AND M. BARTRAM (1989), Penguin Reading Skills, Penguin Books Ltd., London.

\section{Appendix-1}

Learners' Questionnaire

(1) Pre- reading activities

1. Which pre-reading activities are offered by your teacher? (You can tick more than one)

i) Giving idea about the topic 54 (73.97\%)

ii) Arousing interest about the text $37 \mathbf{( 5 0 . 6 8 \% )}$

iii) Matching pictures with various titles $23(\mathbf{3 1 . 5 0 \%})$

iv) Asking questions on the similar objects or ideas discussed in the text $33 \mathbf{( 4 5 . 2 0 \% )}$

v) Asking general questions on the given text 36 (49.31\%)

vi) Asking specific questions on themes / points or about the characters of the text $\mathbf{2 6}$ $(35.61 \%)$

vii) Asking general questions or opinions on the pictures related with the text $\mathbf{2 5}$ (34.24\%)

viii) Asking analytic or reference questions on the text14(19.17\%)

ix) Making you think and discuss in groups about the topic using introduction of the text and given pictures $27 \mathbf{( 3 6 . 9 8 \% )}$

$\mathrm{x})$ Making you think about the time, setting and background of the text $19(\mathbf{2 6 . 0 2 \%})$

xi) Making you work out the story using various pictures $08(\mathbf{1 0 . 9 5 \% )}$ 
IIUC Studies, Vol. 6

\begin{tabular}{|l|}
\hline xii) Asking questions on the pictures of the popular stories $06(8.21 \%)$ \\
\hline xiii) Asking biographical questions on the author of the text $14(\mathbf{1 9 . 1 7 \% )}$ \\
\hline xiv) Asking hypothetical questions on the text $\mathbf{1 7}(\mathbf{2 3 . 2 8 \% )}$ \\
\hline xv) Making you put the taken out sentences in the appropriate gaps $30(\mathbf{4 1 . 0 9 \% )}$ \\
\hline
\end{tabular}

(2) Reading inside the classroom

2. In which cases do you do loud reading in classroom? (You can tick more than one)

\begin{tabular}{|c|c|c|c|c|}
\hline $\begin{array}{l}\text { Pair work and } \\
\text { group work } \\
\mathbf{2 6}(\mathbf{3 5 . 6 \% )}\end{array}$ & $\begin{array}{c}\text { Explaining an } \\
\text { unseen text in } \\
\text { a large class } \\
\mathbf{1 7}(\mathbf{2 3 . 2 8 \% )}\end{array}$ & $\begin{array}{l}\text { Checking the } \\
\text { answers of the } \\
\text { exercises } \\
29(39.72 \%)\end{array}$ & $\begin{array}{c}\text { Practicing } \\
\text { correct } \\
\text { pronunciation, } \\
\text { stress and } \\
\text { intonation } \\
\mathbf{4 8}(65.5 \%)\end{array}$ & $\begin{array}{l}\text { Creating a } \\
\text { scope of } \\
\text { listening } \\
\mathbf{1 0}(\mathbf{1 3 . 6 9 \% )}\end{array}$ \\
\hline
\end{tabular}

3. Which benefits do you enjoy while doing loud reading in classroom? (You can tick more than one)

\begin{tabular}{c|c|c|c|}
\hline $\begin{array}{c}\text { Helps to learn and } \\
\text { practice correct } \\
\text { pronunciation, } \\
\text { stress and } \\
\text { intonation }\end{array}$ & $\begin{array}{c}\text { Helps others to get } \\
\text { benefit by listening } \\
\mathbf{2 4}(\mathbf{3 2 . 8 7 \% )}\end{array}$ & $\begin{array}{c}\text { Teacher can help a } \\
\text { loud reader }\end{array}$ & $\begin{array}{c}\text { Helps students to } \\
\text { develop speaking }\end{array}$ \\
$\mathbf{4 8}(\mathbf{6 5 . 7 5 \% )}$ & & $\mathbf{2 0} \mathbf{2 7 . 3 9 \% )}$ & $\mathbf{5 1}(\mathbf{6 9 . 8 6 \% )})$ \\
\hline
\end{tabular}

4. In which cases do you do silent reading in classroom? (You can tick more than one)

\begin{tabular}{|c|c|c|c|}
\hline $\begin{array}{c}\text { Before doing } \\
\text { exercises under an } \\
\text { unseen text }\end{array}$ & $\begin{array}{c}\text { For any creative } \\
\text { writing following } \\
\text { the passage of the }\end{array}$ & $\begin{array}{c}\text { Before classroom } \\
\text { discussion }\end{array}$ & $\begin{array}{c}\text { Before pair work } \\
\text { and group work }\end{array}$ \\
$\mathbf{4 9 ( 6 7 . 1 2 \% )}$ & $\begin{array}{c}\text { lesson } \\
\mathbf{2 3}(\mathbf{3 1 . 5 0 \%})\end{array}$ & $\mathbf{2 9}(\mathbf{3 9 . 7 2 \% )}$ & $\mathbf{1 8 ( 2 4 . 6 5 \% )}$ \\
\hline
\end{tabular}

5. Which benefits do you enjoy while doing silent reading in classroom? (You can tick more than one)

\begin{tabular}{|c|c|c|c|c|}
\hline $\begin{array}{l}\text { Faster than } \\
\text { loud reading } \\
\mathbf{1 8}(\mathbf{2 4 . 6 5 \% )}\end{array}$ & $\begin{array}{l}\text { Saves time of } \\
\text { the reader } \\
16(21.91 \%)\end{array}$ & $\begin{array}{l}\text { Less energy is } \\
\text { required } \\
\mathbf{1 6}(\mathbf{2 1 . 9 1 \% )}\end{array}$ & $\begin{array}{l}\text { Helps to } \\
\text { understand } \\
\text { text better } \\
\mathbf{4 9 ( 6 7 . 1 2 \% )}\end{array}$ & $\begin{array}{c}\text { Reader can } \\
\text { think } \\
\text { personally } \\
\text { about the text } \\
\mathbf{3 8}(\mathbf{5 2 . 0 5 \%})\end{array}$ \\
\hline
\end{tabular}

6. What benefits do you enjoy in a cooperative class? (You can tick more than one)

\begin{tabular}{|c|c|c|c|}
\hline $\begin{array}{c}\text { Facilitates } \\
\text { understanding of } \\
\text { the unseen text }\end{array}$ & $\begin{array}{c}\text { Inspires you to } \\
\text { participate in } \\
\text { group work and }\end{array}$ & $\begin{array}{c}\text { Allows weaker } \\
\text { students to see how } \\
\text { the better readers } \\
\text { 46(63.01\%) }\end{array}$ & $\begin{array}{c}\text { Classroom lessons } \\
\text { become interesting } \\
\text { and enjoyable }\end{array}$ \\
& $\mathbf{2 4 ( 3 2 . 8 7 \% )}$ & $\mathbf{4 6}(\mathbf{6 3 . 0 1 \% )}$ & $\mathbf{4 9}(\mathbf{6 7 . 1 2 \% )}$ \\
\hline
\end{tabular}

7. What is the percentage of the students' participation in the total duration of the classroom activities?

\begin{tabular}{|c|c|c|c|c|c|}
\hline $5 \%-10 \%$ & $10 \%-15 \%$ & $15 \%-20 \%$ & $20 \%-25 \%$ & $25 \%-30 \%$ & $30 \%-35 \%$ \\
$\mathbf{0 4}$ & $\mathbf{1 5}$ & $\mathbf{1 7}$ & $\mathbf{2 4}$ & $\mathbf{0 6}$ & $\mathbf{0 7}$ \\
$\mathbf{( 5 . 4 7 \% )}$ & $\mathbf{( 2 0 . 5 4 \% )}$ & $\mathbf{( 2 3 . 2 8 \% )}$ & $\mathbf{( 3 2 . 8 7 \% )}$ & $\mathbf{( 8 . 2 1 \% )}$ & $\mathbf{( 9 . 5 8 \% )}$ \\
\hline
\end{tabular}

8. What is the percentage of teacher $>$ student interaction in the total duration of the classroom activities? 
Classroom Situation in Reading Classes of the Foundation English Course (FEC) at International Islamic University Chittagong (IIUC): An Empirical Study

\begin{tabular}{|c|c|c|c|c|c|}
\hline $5 \%-10 \%$ & $10 \%-15 \%$ & $15 \%-20 \%$ & $20 \%-25 \%$ & $25 \%-30 \%$ & $30 \%-35 \%$ \\
$\mathbf{0 3}$ & $\mathbf{0 8}$ & $\mathbf{1 0}$ & $\mathbf{2 8}$ & $\mathbf{1 2}$ & $\mathbf{1 2}$ \\
$\mathbf{( 4 . 1 0 \% )}$ & $\mathbf{( 1 0 . 9 5 \% )}$ & $\mathbf{( 1 3 . 6 9 \% )}$ & $\mathbf{( 3 8 . 3 5 \% )}$ & $\mathbf{( 1 6 . 4 3 \% )}$ & $\mathbf{( 1 6 . 4 3 \% )}$ \\
\hline
\end{tabular}

9. Does your teacher introduce you with the authentic texts in English for pleasure reading?

\begin{tabular}{|l|l|l|}
\hline Yes $32(\mathbf{4 3 . 8 3} \%)$ & No $14(\mathbf{1 9 . 1 7 \% )}$ & Sometimes $27(\mathbf{3 6 . 9 8 \% )}$ \\
\hline
\end{tabular}

10. Does your teacher encourage you to do pleasure reading outside the classroom?

\begin{tabular}{|l|l|l}
\hline Yes $40(54.79 \%)$ & No $17(\mathbf{2 3 . 2 8 \% )}$ & Sometimes $16(\mathbf{2 1 . 9 1 \% )}$
\end{tabular}

11. Does your teacher take time after the lesson to tell you the answer of the exercises and how these answers were arrived at?

\begin{tabular}{|l|l|l} 
Yes $33(45.20 \%)$ & No $14(\mathbf{1 9 . 1 7 \% )}$ & Sometimes $26(35.61 \%)$
\end{tabular}

12. Does your teacher translate every sentence in Bengali while discussing the text in classroom?

\begin{tabular}{|l|l|l} 
Yes $19(\mathbf{2 6 . 0 2 \%} \%)$ & No $15(\mathbf{2 0 . 5 4 \% )}$ & Sometimes $39(\mathbf{5 3 . 4 2 \%})$
\end{tabular}

13. Does your teacher express every sentence easily in English while discussing the text in classroom?

\begin{tabular}{|l|l|l|}
\hline Yes $37(\mathbf{5 0 . 6 8 \%} \%)$ & No $10(\mathbf{1 3 . 6 9 \% )}$ & Sometimes 26 (35.61\%) \\
\hline
\end{tabular}

(3) Reading Lessons

14. Do you think the reading lessons are adequate to help you develop your reading skill?

\begin{tabular}{l|l|l} 
Yes $37(\mathbf{5 0 . 6 8 \%})$ & No $\mathbf{1 5}(\mathbf{2 0 . 5 4 \% )}$ & Sometimes $21(\mathbf{2 8 . 7 6 \% )}$ \\
\hline
\end{tabular}

15. Are your reading lessons grammar and vocabulary focused?

\begin{tabular}{l|l|l} 
Yes $43(58.90 \%)$ & No $06(8.21 \%)$ & Sometimes $24(32.87 \%)$
\end{tabular}

16. On which areas do your reading lessons focus (You can tick more than one)

\begin{tabular}{c|c|c|c}
$\begin{array}{c}\text { Practicing } \\
\text { grammar }\end{array}$ & $\begin{array}{c}\text { Solving exercises } \\
\text { based on the given } \\
\text { text }\end{array}$ & $\begin{array}{c}\text { Communicating } \\
\text { ideas }\end{array}$ & $\begin{array}{c}\text { Understanding the } \\
\text { main idea of the }\end{array}$ \\
text $\mathbf{4 5}(\mathbf{6 1 . 6 4 \% )}$
\end{tabular}

17. Why don't you enjoy reading lessons for the classroom activity? (You can tick more than one)

\begin{tabular}{|c|c|c|c|c|}
\hline $\begin{array}{c}\text { Lessons are } \\
\text { not } \\
\text { chronologicall } \\
\text { y arranged } \\
\mathbf{2 8}(\mathbf{3 8 . 3 5 \% )}\end{array}$ & $\begin{array}{c}\text { Lessons are } \\
\text { difficult and } \\
\text { not interesting } \\
\mathbf{4 1}(\mathbf{5 6 . 1 6 \% )}\end{array}$ & $\begin{array}{c}\text { Teacher } \\
\text { cannot make } \\
\text { the lesson easy } \\
\mathbf{2 0}(\mathbf{2 7 . 3 9 \% )}\end{array}$ & $\begin{array}{c}\text { Teacher is not } \\
\text { enthusiastic } \\
\text { and } \\
\text { encouraging } \\
\mathbf{1 5} \text { (20.54) }\end{array}$ & $\begin{array}{l}\text { Lessons not } \\
\text { structured for } \\
\text { classroom } \\
\text { practice and } \\
\text { discussion } \\
\mathbf{3 1}(\mathbf{4 2 . 4 6 \% )}\end{array}$ \\
\hline
\end{tabular}

18. Why are your reading lessons not interesting? (You can tick more than one)

\begin{tabular}{|c|c|c|c|}
\hline $\begin{array}{c}\text { Difficult } \\
\text { structure, new } \\
\text { words and } \\
\text { phrases } \\
\mathbf{5 6}(\mathbf{7 6 . 7 1 \% )}\end{array}$ & $\begin{array}{c}\text { Topics not matching } \\
\text { our social culture and } \\
\text { mentality of the } \\
\text { students } \\
\mathbf{3 3}(\mathbf{4 5 . 2 0 \% )}\end{array}$ & $\begin{array}{c}\text { Teacher cannot } \\
\text { make the lesson } \\
\text { easy } \\
\mathbf{2 1 ( 2 8 . 7 6 \% )}\end{array}$ & $\begin{array}{c}\text { Discouraging } \\
\text { personality of the } \\
\text { teacher } \\
\mathbf{1 2}(\mathbf{1 6 . 4 3 \% )}\end{array}$ \\
\hline
\end{tabular}


IIUC Studies, Vol. 6

(4) Vocabulary

19. Do you ignore or skip over difficult words while doing reading?

\begin{tabular}{|l|l|l|}
\hline Yes $13(\mathbf{1 7 . 8 0} \%)$ & No $30(\mathbf{4 1 . 0 9 \% )}$ & Sometimes $30 \mathbf{( 4 1 . 0 9 \% )}$ \\
\hline $\mathbf{2 0}$. Do you translate every word while doing reading? \\
\hline Yes $\mathbf{2 9}(\mathbf{3 9 . 7 2 \%})$ & No $\mathbf{1 4}(\mathbf{1 9 . 1 7 \% )}$ & Sometimes $30(\mathbf{4 1 . 0 9 \%})$ \\
\hline
\end{tabular}

21. Do you usually become worried after seeing difficult words while reading an unseen text?

\begin{tabular}{|l|l|l|}
\hline Yes $37 \mathbf{( 5 0 . 6 8 \% )}$ & No $\mathbf{1 0}(\mathbf{1 3 . 6 9 \% )}$ & Sometimes $\mathbf{2 6} \mathbf{( 3 5 . 6 1 \% )}$
\end{tabular}

22. Are you habituated to guessing meaning of unknown words while reading unseen text?

\begin{tabular}{|l|l|l|} 
Yes $28(\mathbf{3 8 . 3 5 \% )}$ & No $\mathbf{1 0} \mathbf{( 1 3 . 6 9 \% )}$ & Sometimes $35 \mathbf{( 4 7 . 9 4 \% )}$ \\
\hline
\end{tabular}

23. Do you use English to English dictionary to find the meaning of unknown words?

\begin{tabular}{|l|l|l} 
Yes $30(\mathbf{4 1 . 0 9 \% )}$ & No $12(\mathbf{1 6 . 4 3 \% )}$ & Sometimes $31 \mathbf{( 4 2 . 4 6 \% )}$
\end{tabular}

24. Do you maintain Vocabulary Note Book to note down the meaning of unknown words?

\begin{tabular}{l|l|l} 
Yes $39(\mathbf{5 3 . 4 2 \% )}$ & No $06(8.21 \%)$ & Sometimes 28 (38.35\%)
\end{tabular}

25. How many hours do you spend regularly for using English-English dictionary outside the classroom?

\begin{tabular}{|c|c|c|c|c|c|}
\hline 30 minutes & 45 minutes & 90 minutes & 2 hours & 2.5 hours & 3 hours \\
$\mathbf{3 9}(\mathbf{5 3 . 4 2} \%)$ & $\mathbf{1 4 ( 1 9 . 1 7 \% )}$ & $\mathbf{0 7}(\mathbf{9 . 5 8 \%})$ & $\mathbf{0 8}(\mathbf{1 0 . 9 5 \% )}$ & $\mathbf{0 1}(\mathbf{1 . 3 6 \% )}$ & $\mathbf{0 4}(\mathbf{5 . 4 7 \%})$ \\
\hline
\end{tabular}

(5) Evaluation System

26. Do you think that the evaluation system is faulty and not encouraging for you? Yes 40(54.79\%) No 33(45.20\%)

27. How many class tests have your reading teacher taken out of approximately sixty (60) classes?

\begin{tabular}{|c|c|c|c|c|c|c|}
\hline $\begin{array}{l}2 \\
22(30.13 \%)\end{array}$ & $\begin{array}{l}3 \\
06(8.21 \%)\end{array}$ & $\begin{array}{l}4 \\
43(58.90 \%)\end{array}$ & $\begin{array}{l}6 \\
01(1.36 \%)\end{array}$ & $\begin{array}{l}8 \\
01(1.36 \%)\end{array}$ & 10 & 12 \\
\hline \multicolumn{7}{|c|}{ 28. What were the components of your class tests? (You can tick more than one) } \\
\hline \multicolumn{3}{|c|}{ i) Vocabulary 46(63.01\%) } & \multicolumn{4}{|c|}{ ii) Multiple -choice items 39(53.42\%) } \\
\hline \multicolumn{3}{|c|}{ iii) Matching items $48(65.75 \%)$} & \multicolumn{4}{|c|}{ iv) True/false items $\mathbf{5 5 ( 7 5 . 3 4 \% )}$} \\
\hline \multicolumn{3}{|c|}{ v) Completing sentences $\mathbf{1 8}(\mathbf{2 4 . 6 5 \%})$} & \multicolumn{4}{|c|}{ vi) Summarizing the text $\mathbf{3 7 ( 5 0 . 6 8 \% )}$} \\
\hline \multicolumn{3}{|c|}{$\begin{array}{l}\text { vii) Argument analysis from the text } \\
\mathbf{1 4 ( 1 9 . 1 7 \% )}\end{array}$} & \multicolumn{4}{|c|}{$\begin{array}{l}\text { viii) Making dialogue on the text topic } \\
\mathbf{2 2 ( 3 0 . 1 3 \% )}\end{array}$} \\
\hline
\end{tabular}

(6) Learner

29. Do you feel enthusiastic to attend the reading class?

\begin{tabular}{l|l|l} 
Yes $50(\mathbf{6 8 . 4 9 \%})$ & No $09(\mathbf{1 2 . 3 2 \% )}$ & Sometimes $\mathbf{1 4} \mathbf{( 1 9 . 1 7 \% )}$
\end{tabular}

30. Do you maintain a list of problems, found while doing pleasure reading, to be discussed in the classroom?

\begin{tabular}{|l|l|l} 
Yes $\mathbf{1 5}(\mathbf{2 0 . 5 4 \% )}$ & No $26 \mathbf{( 3 5 . 6 1 \% )}$ & Sometimes $32 \mathbf{( 4 3 . 8 3 \% )}$
\end{tabular}

31. Why is your development in reading competence not satisfactory? (You can tick more than one)

i) Due to lack of proper teaching $18(\mathbf{2 4 . 6 5 \% )}$

ii) Due to inefficient teacher $10(\mathbf{1 3 . 6 9 \% )}$

iii) Due to your own negligence $36(49.31 \%)$ 
iv) Due to no clear idea about practicing reading 41 (56.16\%)

v) Due to uninteresting text $34 \mathbf{( 4 6 . 5 7 \% )}$

vi) Due to unspecific target/goal 14 (19.17\%)

vii) Due to lack of regular reading of authentic text in English $33 \mathbf{( 4 5 . 2 0 \% )}$

viii) Due to lack of using English-English dictionary 31 (42.46\%)

(7) Teacher

32. Does your teacher take enough preparation for the class?

\begin{tabular}{|l|l|l} 
Yes 45(61.64\%) & No 12(16.43\%) & Sometimes 16(21.91\%)
\end{tabular}

33. Do you find the teacher sincere and punctual in classroom?

\begin{tabular}{|l|l|l} 
Yes 43(58.90\%) & No $\mathbf{1 2 ( 1 6 . 4 3 \% )}$ & Sometimes $\mathbf{1 8 ( 2 4 . 6 5 \% )}$
\end{tabular}

34. How do you find your teacher in classroom?

\begin{tabular}{|l|l|l|l} 
Friend 01 (1.36\%) & $\begin{array}{l}\text { Facilitator 05 } \\
\mathbf{( 6 . 8 4 \% )}\end{array}$ & $\begin{array}{l}\text { Lecturer 28 } \\
\mathbf{( 3 8 . 3 5 \% )}\end{array}$ & $\begin{array}{l}\text { Both friend and } \\
\text { facilitator 39 } \\
\mathbf{5 3 . 4 2 \% )}\end{array}$ \\
\hline
\end{tabular}

35. Does your teacher make planning for giving an interesting class?

\begin{tabular}{l|l|l} 
Yes 37(50.68\%) & No $\mathbf{1 5 ( 2 0 . 5 4 \% )}$ & Sometimes 21(28.76\%)
\end{tabular}

36. Do you get sympathetic treatment from your teacher in case of making wrong meanings from the context?

\begin{tabular}{|l|l|l} 
Yes 49(67.12\%) & No $\mathbf{0 6}(\mathbf{8 . 2 1} \%)$ & Sometimes $\mathbf{1 8 ( 2 4 . 6 5 \% )}$ \\
\hline
\end{tabular}

37. Does your teacher correct your mistakes instantly?

\begin{tabular}{|l|l|l}
\hline Yes $61(\mathbf{8 3 . 5 6 \% )}$ & No $04(\mathbf{5 . 4 7 \% )}$ & Sometimes $08(\mathbf{1 0 . 9 5 \% )}$ \\
\hline
\end{tabular}

(8) Teaching Technique

38. How does your teacher identify your problem before imparting a lesson? (You can tick more than one)

i) Taking a test on vocabulary used in the text $\mathbf{3 7 ( 5 0 . 6 8 \% )}$

ii) Making you guess meaning of unknown words of the text $46(63.01 \%)$

iii) Taking a test on using correct sentence structure used in the text $\mathbf{2 9}(\mathbf{3 9 . 7 2 \%})$

iv) Asking you small questions on particular sentence structures used in the text 41(56.16\%)

v) Making you answer questions on the text $\mathbf{3 6}(\mathbf{4 9 . 3 1 \% )}$

vi) Asking you to give a general idea of the text 39(53.42\%)

vii) Making you read and explain some lines 32(43.83\%)

viii) Making you read and explain some lines in group discussion 30(41.09\%)

39. How does your teacher give you feed back about your improvement in reading competence? (You can tick more than one)

\begin{tabular}{l|l|l|l|}
$\begin{array}{l}\text { Pointing out the } \\
\text { mistakes without } \\
\text { insulting }\end{array}$ & $\begin{array}{l}\text { Making } \\
\text { friendly } \\
\text { behaviour }\end{array}$ & $\begin{array}{l}\text { Taking class tests } \\
\text { at regular intervals }\end{array}$ & $\begin{array}{l}\text { Encouraging to } \\
\text { participate in group work } \\
\text { \& pair work 23(31.50\%) }\end{array}$ \\
\hline
\end{tabular}

40. Do you find the teaching method followed by your teacher effective?

\begin{tabular}{|l|l|l|}
\hline Yes 34(46.57\%) & No $\mathbf{1 3}(\mathbf{1 7 . 8 0} \%)$ & Sometimes $\mathbf{2 6 ( 3 5 . 6 1 \% )}$ \\
\hline 41. Does your teacher always follow the same teaching technique in all the classes? \\
\hline Yes $\mathbf{2 9}(\mathbf{3 9 . 7 2} \%)$ & No $\mathbf{2 1}(\mathbf{2 8 . 7 6} \%)$ & Sometimes $\mathbf{2 3 ( 3 1 . 5 0 \% )}$ \\
\hline
\end{tabular}


Appendix-2

Teachers' Questionnaire

(1) Pre- reading activities

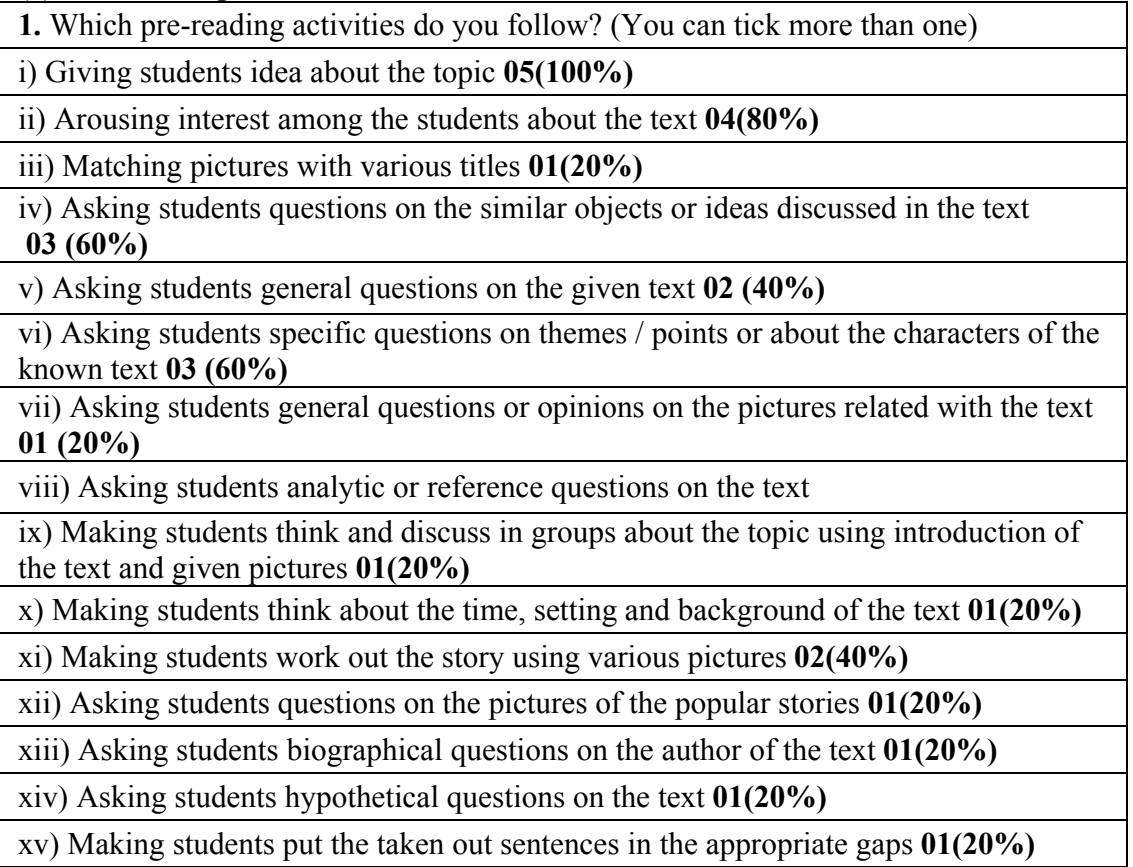

(2) Reading inside the classroom

2. In which cases do you conduct loud reading in classroom? (You can tick more than one)

\begin{tabular}{|c|c|c|c|c|}
\hline $\begin{array}{l}\text { Pair work } \\
\text { and group } \\
\text { work } \\
\mathbf{0 1}(\mathbf{2 0 \%})\end{array}$ & $\begin{array}{l}\text { Explaining } \\
\text { an unseen } \\
\text { text in a } \\
\text { large class } \\
\mathbf{0 1}(\mathbf{2 0 \%})\end{array}$ & $\begin{array}{l}\text { Checking } \\
\text { the } \\
\text { answers } \\
\text { of the } \\
\text { exercises } \\
\mathbf{0 3}(\mathbf{6 0 \%})\end{array}$ & $\begin{array}{l}\text { Practicing correct } \\
\text { pronunciation, stress and } \\
\text { intonation } \\
\mathbf{0 4}(\mathbf{8 0} \%)\end{array}$ & $\begin{array}{l}\text { Creating a } \\
\text { scope of } \\
\text { listening } \\
\mathbf{0 1}(\mathbf{2 0 \%})\end{array}$ \\
\hline
\end{tabular}

3. Which benefits do the students get while doing loud reading in classroom? (You can tick more than one)

\begin{tabular}{|c|c|c|c|}
\hline & $\begin{array}{c}\text { Helps } \\
\text { others to }\end{array}$ & Telps to learn and practice & get \\
correct pronunciation, & benefit & Teacher can help a loud & students to \\
stress and intonation & reader & develop \\
$\mathbf{0 4}(\mathbf{8 0 \% )}$ & by & $\mathbf{0 3 ~ ( 6 0 \% )}$ & speaking \\
& listening & & $\mathbf{0 2}(\mathbf{4 0 \% )}$ \\
& $\mathbf{0 3}(\mathbf{6 0 \%})$ & & \\
\hline
\end{tabular}

4. In which cases do you conduct silent reading in classroom? (You can tick more than one) 


\begin{tabular}{|c|c|c|c|}
\hline $\begin{array}{c}\text { Before doing } \\
\text { exercises under an } \\
\text { unseen text } \\
\mathbf{0 3}(\mathbf{6 0 \%})\end{array}$ & $\begin{array}{c}\text { For any creative } \\
\text { writing } \\
\text { following the } \\
\text { passage of the } \\
\text { lesson } \\
\mathbf{0 3}(\mathbf{6 0 \%} \%)\end{array}$ & $\begin{array}{c}\text { Before classroom } \\
\text { discussion } \\
\mathbf{0 3}(\mathbf{6 0 \% )}\end{array}$ & $\begin{array}{c}\text { Before pair } \\
\text { work and } \\
\text { group work } \\
\mathbf{0 2}(\mathbf{4 0 \% )}\end{array}$ \\
\hline
\end{tabular}

5. Which benefits do the students get while doing silent reading in classroom? (You can tick more than one)

\begin{tabular}{|c|c|c|c|c|}
\hline $\begin{array}{l}\text { Faster than } \\
\text { loud reading }\end{array}$ & $\begin{array}{l}\text { Saves } \\
\text { time of } \\
\text { the } \\
\text { reader } \\
\mathbf{0 1} \\
(\mathbf{2 0 \%})\end{array}$ & $\begin{array}{l}\text { Less energy is } \\
\text { required } \\
\mathbf{0 2}(\mathbf{4 0 \% )}\end{array}$ & $\begin{array}{l}\text { Helps to understand } \\
\text { text better } \\
\mathbf{0 1}(\mathbf{2 0 \% )}\end{array}$ & $\begin{array}{c}\text { Reader can } \\
\text { think } \\
\text { personally } \\
\text { about the } \\
\text { text } \mathbf{0 5} \\
(\mathbf{1 0 0 \% )}\end{array}$ \\
\hline
\end{tabular}

6. What benefits do the students get in a cooperative class? (You can tick more than one)

\begin{tabular}{|c|c|c|c|}
\hline $\begin{array}{c}\text { Facilitates } \\
\text { understanding of the } \\
\text { unseen text }\end{array}$ & $\begin{array}{c}\text { Inspires } \\
\text { you to } \\
\text { participate } \\
\text { in group } \\
\text { work and }\end{array}$ & $\begin{array}{c}\text { Classroom } \\
\text { lessons } \\
\text { become } \\
\text { Allows weaker students to see } \\
\text { pair work }\end{array}$ & $\begin{array}{c}\text { howteresting } \\
\text { and }\end{array}$ \\
& $\mathbf{0 3 ( 6 0 \% )}$ & $\mathbf{0 4}(\mathbf{8 0 \% )}$ & $\begin{array}{c}\text { enjoyable } \\
\mathbf{0 4}(\mathbf{8 0 \%})\end{array}$ \\
\hline
\end{tabular}

7. What is the percentage of the students' participation in the total duration of the classroom activities?

\begin{tabular}{|l|l|l|l|l|l|}
\hline $5 \%-10 \%$ & $10 \%-15 \%$ & $15 \%-20 \%$ & $\begin{array}{l}20 \%-25 \% \\
\mathbf{0 1}(\mathbf{2 0} \%)\end{array}$ & $\begin{array}{l}25 \%-30 \% \\
\mathbf{0 4 ( 8 0 \% )}\end{array}$ & $30 \%-35 \%$ \\
\hline
\end{tabular}

8. What is the percentage of teacher $>$ student interaction in the total duration of the classroom activities?

\begin{tabular}{|l|l|l|l|l|l|}
\hline $5 \%-10 \%$ & $10 \%-15 \%$ & $15 \%-20 \%$ & $\begin{array}{l}20 \%-25 \% \\
\mathbf{0 1}(\mathbf{2 0 \%})\end{array}$ & $\begin{array}{l}25 \%-30 \% \\
\mathbf{0 3}(\mathbf{6 0} \%)\end{array}$ & $\begin{array}{l}30 \%-35 \% \\
\mathbf{0 1}(\mathbf{2 0 \%})\end{array}$ \\
\hline
\end{tabular}

9. Do you introduce the students with the authentic texts in English for pleasure reading?

\begin{tabular}{l|l|l}
\hline Yes $03(60 \%)$ & No & Sometimes $02(\mathbf{4 0 \%})$
\end{tabular}

10. Do you encourage the students to do pleasure reading outside the classroom?

\begin{tabular}{l|l|l} 
Yes $04 \mathbf{( 8 0 \% )}$ & No & Sometimes $01 \mathbf{( 2 0 \% )}$
\end{tabular}

11. Do you give time after the lesson to tell the students the answer of the exercises and how these answers were arrived at?

\begin{tabular}{|l|l|l} 
Yes $04(80 \%)$ & No & Sometimes $01(\mathbf{2 0 \%})$
\end{tabular}

12. Do you translate every sentence in Bengali while discussing the text in classroom?

\begin{tabular}{l|l|l}
\hline Yes & No $01(\mathbf{2 0} \%)$ & Sometimes $04(\mathbf{8 0 \%})$
\end{tabular}

13. Do you express every sentence easily in English while discussing the text in classroom?

\begin{tabular}{|l|l|l}
\hline Yes $04(\mathbf{8 0} \%)$ & No & Sometimes $01(\mathbf{2 0} \%)$
\end{tabular}

(3) Reading Lessons

14. Do you feel the number reading lessons used by you is enough to develop reading competence among the learners?

\begin{tabular}{|l|l|l|} 
Yes $03(60 \%)$ & No $01(20 \%)$ & Sometimes $01(\mathbf{2 0} \%)$ \\
\hline
\end{tabular}

15. Are your reading lessons grammar and vocabulary focused?

\begin{tabular}{|c|c|c|} 
Yes $02(40 \%)$ & No & Sometimes $03(60 \%)$ \\
\hline
\end{tabular}




\begin{tabular}{|c|c|c|c|c|c|c|c|}
\hline \multicolumn{8}{|c|}{ ur reading lessons mainly focus (You can tick more than } \\
\hline $\begin{array}{l}\text { Practicing } \\
\text { grammar \& } \\
\text { vocabulary } \\
\mathbf{0 4}(\mathbf{8 0 \%}) \\
\end{array}$ & \multicolumn{3}{|c|}{$\begin{array}{l}\text { Reproducing ideas of } \\
\text { the text }\end{array}$} & \multicolumn{2}{|c|}{$\begin{array}{c}\text { Communicating } \\
\text { ideas } \\
\mathbf{0 2}(\mathbf{4 0 \% )}\end{array}$} & \multicolumn{2}{|c|}{$\begin{array}{l}\text { Understanding the main } \\
\text { idea of the text } \\
\mathbf{0 5}(\mathbf{1 0 0 \% )}\end{array}$} \\
\hline \multicolumn{8}{|c|}{$\begin{array}{l}\text { 17. In which cases students do not enjoy your reading lessons? (You can tick more } \\
\text { than one) }\end{array}$} \\
\hline $\begin{array}{l}\text { Topics not } \\
\text { matching with } \\
\text { students' } \\
\text { social culture } \\
\mathbf{0 4 ( 8 0 \% )}\end{array}$ & \multicolumn{2}{|c|}{\begin{tabular}{|c} 
Language of \\
the lessons not \\
suitable to their \\
levels \\
$\mathbf{0 4 ( 8 0 \% )}$
\end{tabular}} & \multicolumn{2}{|c|}{$\begin{array}{l}\text { Lessons not } \\
\text { structured for } \\
\text { classroom } \\
\text { practice and } \\
\text { discussion }\end{array}$} & \multicolumn{2}{|c|}{$\begin{array}{c}\text { Teaching } \\
\text { without } \\
\text { proper } \\
\text { planning } \\
\mathbf{0 2}(\mathbf{4 0 \% )}\end{array}$} & \begin{tabular}{|c} 
Teaching \\
without arousing \\
interest among \\
the learners \\
$\mathbf{0 3}(\mathbf{6 0 \%})$
\end{tabular} \\
\hline \multicolumn{8}{|c|}{ 18. Which sources do you use for the reading lessons? } \\
\hline $\begin{array}{c}\text { Newspaper } \\
\text { articles \& } \\
\text { magazines } \\
\mathbf{0 4 ( 8 0 \% )}\end{array}$ & $\begin{array}{l}\text { TOEFL } \\
\text { guide } \\
\mathbf{0 1}(\mathbf{2 0 \%})\end{array}$ & \multicolumn{3}{|c|}{$\begin{array}{l}\text { Headway Series } \\
03(\mathbf{6 0 \%})\end{array}$} & $\begin{array}{l}\text { Short } \\
\text { stories } \\
\mathbf{0 2} \\
(\mathbf{4 0 \%})\end{array}$ & \multicolumn{2}{|c|}{$\begin{array}{c}\text { Prescribed book of Open } \\
\text { University (International } \\
\text { English Book) } \mathbf{0 1} \\
(\mathbf{2 0 \% )}\end{array}$} \\
\hline
\end{tabular}

(4) Vocabulary

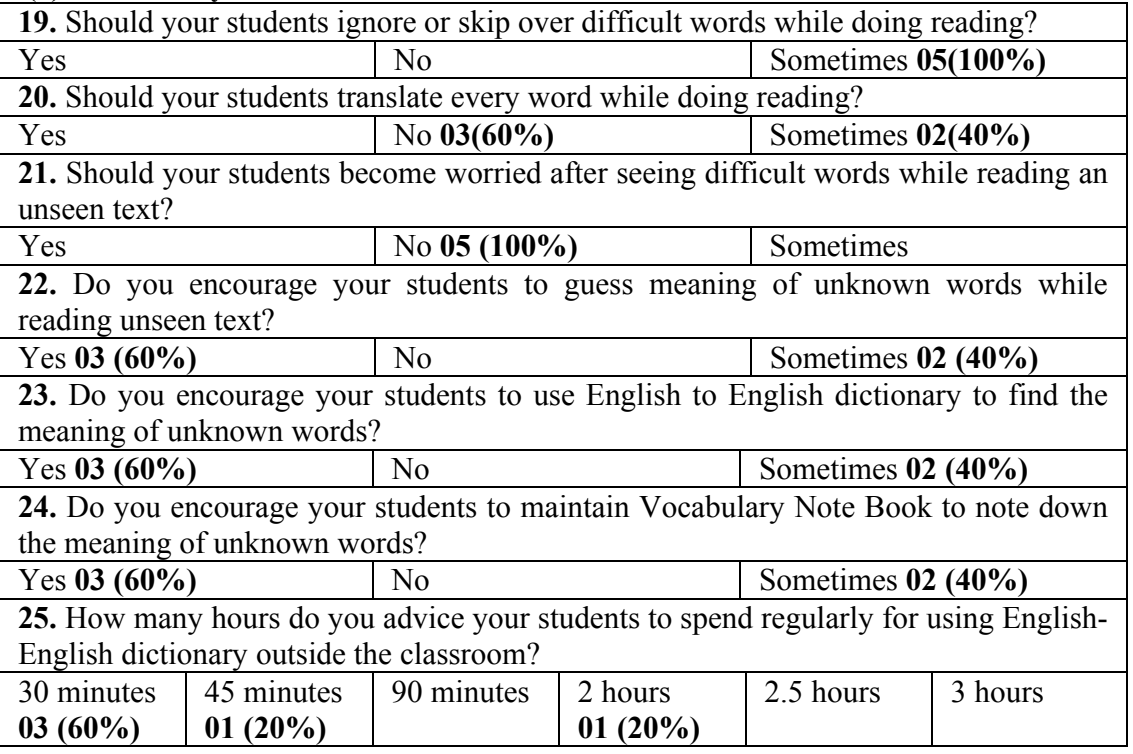

(5) Evaluation System

26. Do you think that the existing evaluation system is enough to give feedback for the students' development in their reading competence?

\begin{tabular}{|c|c|c|c|c|c|}
\hline \multicolumn{2}{|c|}{ Yes $01(\mathbf{2 0} \%)$} & \multicolumn{2}{|c|}{ No $01(\mathbf{2 0} \%)$} & \multicolumn{2}{|c|}{ Sometimes $03(60 \%)$} \\
\hline \multicolumn{6}{|c|}{ 27. How many class tests have you taken out of approximately sixty (60) classes? } \\
\hline \begin{tabular}{l|l}
4 & 1 \\
\end{tabular} & $6 \quad \mathbf{0 3}(\mathbf{6 0 \%})$ & \begin{tabular}{|l|l|} 
& 8 \\
\end{tabular} & \begin{tabular}{l|l|} 
& 10 \\
\end{tabular} & $02(40 \%)$ & 12 \\
\hline \multicolumn{6}{|c|}{ 28. What were the components of your class tests? (You can tick more than one) } \\
\hline \multicolumn{3}{|c|}{ i) Vocabulary $04(80 \%)$} & \multicolumn{3}{|c|}{ ii) Multiple -choice items 01 (20\%) } \\
\hline
\end{tabular}




\begin{tabular}{|l|l|}
\hline iii) Matching items $03(60 \%)$ & iv) True/false items $03(\mathbf{6 0} \%)$ \\
\hline v) Completing sentences & vi) Summarizing the text $\mathbf{0 3}(\mathbf{6 0} \%)$ \\
\hline $\begin{array}{l}\text { vii) Argument analysis from the text } \\
\mathbf{0 2}(\mathbf{4 0 \% )}\end{array}$ & viii) Making dialogue on the text topic \\
\hline
\end{tabular}

(6) Learner

29. Are the learners enthusiastic /serious about their participation in the classroom activities?

\begin{tabular}{|l|l|l}
\hline Yes $03(\mathbf{6 0 \%})$ & No & Sometimes $02 \mathbf{( 4 0 \% )}$
\end{tabular}

30. Do your students maintain a list of problems, found while doing pleasure reading, to be discussed in the classroom?

\begin{tabular}{|l|l|l} 
Yes & No $01 \mathbf{( 2 0 \% )}$ & Sometimes $04 \mathbf{( 8 0 \% )}$ \\
\hline .
\end{tabular}

31. Why is the development of your students in reading competence not satisfactory? (You can tick more than one)

i) Due to lack of proper care/guidance/monitoring 01 (20\%)

ii) Due to less motivated / overloaded teacher 01 (20\%)

\begin{tabular}{|l|l} 
iii) Due to negligence of students & iv) Due to unplanned classes $03(60 \%)$
\end{tabular} $04(80 \%)$

v) Due to uninteresting text vi) Lack of timely and regular feedback \begin{tabular}{l|l}
$01(20 \%)$ & $01(20 \%)$
\end{tabular}

vii) Due to lack of regular reading of authentic text in English by students $02(\mathbf{4 0 \%})$

viii) Due to lack of using English-English dictionary by students $02(40 \%)$

(7)Teacher

32. Do you get enough time to take preparation for the class?

\begin{tabular}{|l|l|l|}
\hline Yes $01(\mathbf{2 0} \%)$ & No $01(\mathbf{2 0 \%})$ & Sometimes $03 \mathbf{( 6 0 \% )}$
\end{tabular}

33. Can you ensure sincerity and punctuality in classroom?

\begin{tabular}{|l|l|l|}
\hline Yes $01(\mathbf{2 0} \%)$ & No $01(\mathbf{2 0 \%})$ & Sometimes $03(\mathbf{6 0 \%})$ \\
\hline $34.6 h a t)$ &
\end{tabular}

34. What should be the role of a teacher in a classroom?

\begin{tabular}{|l|c|c|c|} 
Friend & Facilitator 01 (20\%) & Lecturer & $\begin{array}{c}\text { Both friend and facilitator } \\
\mathbf{0 4}(\mathbf{8 0 \%})\end{array}$ \\
\hline
\end{tabular}

35. Do you make planning for giving an interesting class?

\begin{tabular}{|l|l|l} 
Yes $01(\mathbf{2 0} \%)$ & No & Sometimes $04 \mathbf{( 8 0 \% )}$
\end{tabular}

36. Do you treat students with sympathy in case of their making wrong meanings from the context?

\begin{tabular}{|c|c|c|}
\hline Yes $03(60 \%)$ & No & Sometimes $02(40 \%)$ \\
\hline \multicolumn{3}{|c|}{ 37. Do you correct your students' mistakes instantly? } \\
\hline Yes $04(80 \%)$ & No & Sometimes $01(\mathbf{2 0} \%)$ \\
\hline
\end{tabular}

38. Do your students have favourable feelings for teachers, classmates and the procedure of conducting reading class?

Yes 05 (100\%)

39. Do your students have favourable feelings for reading materials?

\begin{tabular}{|l|l} 
Yes $04 \mathbf{( 8 0 \% )}$ & No 01(20\%) \\
\hline
\end{tabular}

40. What is the attitude of your students towards reading class environment?

\begin{tabular}{|l|l|l|l|}
$\begin{array}{l}\text { They are enthusiastic } \\
\mathbf{0 1}(\mathbf{2 0} \%)\end{array}$ & $\begin{array}{l}\text { They like } \\
\mathbf{0 2} \mathbf{( 4 0 \% )}\end{array}$ & They dislike & $\begin{array}{l}\text { They are indifferent } \\
\mathbf{0 2} \mathbf{( 4 0 \% )}\end{array}$ \\
\hline
\end{tabular}

41. What is the attitude of your students towards reading course under FEC? 


\begin{tabular}{|c|c|c|c|c|c|c|}
\hline \multicolumn{2}{|c|}{$\begin{array}{l}\text { They are enthusiastic } \\
\mathbf{0 2}(\mathbf{4 0 \%})\end{array}$} & They like & \multicolumn{2}{|c|}{$\begin{array}{l}\text { They dislike } \\
\mathbf{0 1}(\mathbf{2 0 \%})\end{array}$} & \multicolumn{2}{|c|}{$\begin{array}{l}\text { They are indifferent } \\
\mathbf{0 2}(\mathbf{4 0 \% )}\end{array}$} \\
\hline \multicolumn{7}{|c|}{ 42. What is the attitude of your students towards subject matter of reading lessons? } \\
\hline \multicolumn{2}{|c|}{$\begin{array}{l}\text { They are enthusiastic } \\
\mathbf{0 1}(\mathbf{2 0 \%})\end{array}$} & \begin{tabular}{|l} 
They like \\
$\mathbf{0 3}(\mathbf{6 0 \%})$
\end{tabular} & \multicolumn{2}{|c|}{ They dislike } & \multicolumn{2}{|c|}{$\begin{array}{l}\text { They are indifferent } \\
\mathbf{0 1}(\mathbf{2 0 \%})\end{array}$} \\
\hline \multicolumn{7}{|c|}{ 43. In which areas do the students have shortcoming? (You can tick more than one) } \\
\hline $\begin{array}{l}\text { Reading } \\
\text { ability } \\
\mathbf{0 2}(\mathbf{4 0 \% )}\end{array}$ & $\begin{array}{l}\text { Guessing } \\
\text { the } \\
\text { meaning of } \\
\text { a word } \\
\mathbf{0 3}(\mathbf{6 0 \%} \%)\end{array}$ & $\begin{array}{l}\text { Vocabulary } \\
04(80 \%)\end{array}$ & $\begin{array}{c}\text { Grammar } \\
\mathbf{0 4} \\
\mathbf{( 8 0 \% )}\end{array}$ & $\begin{array}{l}\text { Unc } \\
\text { imp } \\
\text { sug } \\
\mathbf{0 2}\end{array}$ & $\begin{array}{l}\text { standi } \\
\text { g } \\
\text { cation } \\
\text { d } \\
\text { estion } \\
(0 \%)\end{array}$ & $\begin{array}{l}\text { Interpretation } \\
01(\mathbf{2 0} \%)\end{array}$ \\
\hline
\end{tabular}

(8)Teaching Technique

44. How do you identify the problems of your students before imparting a lesson? (You can tick more than one)

i) Taking a test on vocabulary used in the text $\mathbf{0 3 ( 6 0 \% )}$

ii) Making students guess meaning of unknown words of the text $\mathbf{0 3 ( 6 0 \% )}$

iii) Taking a test on using correct sentence structure used in the text $\mathbf{0 1}(\mathbf{2 0 \%})$

iv) Asking students small questions on particular sentence structures used in the text $02(40 \%)$

v) Making students answer questions on the text $\mathbf{0 2}(\mathbf{4 0} \%)$

vi) Asking students to give a general idea of the text $04(80 \%)$

vii) Making students read and explain some lines 04(80\%)

viii) Making students read and explain some lines in group discussion $\mathbf{0 3 ( 6 0 \% )}$

45. How do you motivate your students about their improvement in reading competence? (You can tick more than one)

\begin{tabular}{|c|c|c|c|}
\hline $\begin{array}{l}\text { Pointing out the } \\
\text { mistakes } \\
\text { without } \\
\text { insulting } \\
\mathbf{0 3 ( 6 0 \% )}\end{array}$ & $\begin{array}{l}\text { Making } \\
\text { friendly } \\
\text { behaviour } \\
\mathbf{0 3}(\mathbf{6 0 \%})\end{array}$ & $\begin{array}{l}\text { Taking class } \\
\text { tests at regular } \\
\text { intervals } \\
\mathbf{0 3}(\mathbf{6 0 \%})\end{array}$ & $\begin{array}{l}\text { Encouraging to participate in } \\
\text { group work \& pair work even after } \\
\text { making frequent mistakes } \\
\mathbf{0 2}(\mathbf{4 0 \% )}\end{array}$ \\
\hline
\end{tabular}

46. Do you consider the classroom situation before selecting the teaching technique?

\begin{tabular}{|l|l|l} 
Yes $03(60 \%)$ & No & Sometimes 02 (40\%)
\end{tabular}

47. Do you follow the same teaching technique in all the classes/ for all lessons?

\begin{tabular}{|l|l|l} 
Yes & No $01 \mathbf{( 2 0 \% )}$ & Sometimes $04 \mathbf{( 8 0 \% )}$
\end{tabular}

48. Do you share your experience in the classroom with your colleagues who teach reading skill?

\begin{tabular}{|l|l|l} 
Yes $03(\mathbf{6 0} \%)$ & No & Sometimes 02 (40\%)
\end{tabular}

49. What role do you perform while the reading is actually going on?

\begin{tabular}{|l|l|l}
\hline Monitor 03 (60\%) & Supporter 02(40\%) & Advisor
\end{tabular}

